International Journal of Current Advanced Research

ISSN: O: 2319-6475, ISSN: P: 2319 - 6505, Impact Factor: SJIF: 5.995

Available Online at www.journalijcar.org

Volume 6; Issue 4; April 2017; Page No. 3172-3174

DOI: http://dx.doi.org/10.24327/ijcar.2017.3174.0215

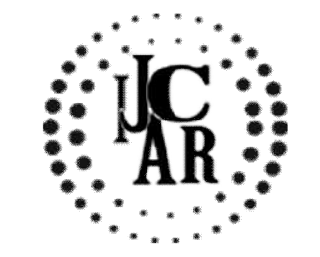

Research Article

\title{
KNOWLEDGE AND AWARENESS OF VARICELLA ZOSTER AMONG THE DENTAL STUDENTS
}

\author{
Induja M.P and Dhanraj
}

BDS Saveetha Dental College and Hospitals, Poonamalle High Road, Chennai

\begin{tabular}{l}
\hline A R T I C L E I N F O \\
\hline Article History: \\
Received $19^{\text {th }}$ January, 2017 \\
Received in revised form $19^{\text {th }}$ February, 2017 \\
Accepted $25^{\text {th }}$ March, 2017 \\
Published online $28^{\text {th }}$ April, 2017 \\
\hline
\end{tabular}

Key words:

Herpesvirus, chicken pox, neurologic conditions, cranial cervical gangilia.

\begin{abstract}
A B S T R A C T
Background: Varicella zoster virus (VZV) is one of eight herpesviruses known to infect humans. VZV infections are species-specific to humans. It causes chickenpox (varicella), a disease most commonly affecting children, teens and young adults and herpes zoster (shingles) in older adults; shingles is rare in children. VZV is known by many names, including chickenpox virus, varicella virus, zoster virus, and human herpesvirus type 3 (HHV-3) VZV multiplies in the lungs, and causes a wide variety of symptoms. After the primary infection (chickenpox), the virus goes dormant in the nerves, including the cranial nerve ganglia, dorsal root ganglia, and autonomic ganglia. Many years after the patient has recovered from chickenpox, VZV can reactivate to cause neurologic conditions

Aim and Objective: To observe and analyse knowledge of Varicella Zoster among the students in dentistry. To identify the awareness of Varicella Zoster in dental students.

Materials and Methods: A questionnaire was circulated among various dental students of different colleges in Chennai. The questionnaire consists of demographic profile and questionnaire related to knowledge regarding varicella zoster virus .Closed ended questionnaire was constructed with a total of 10 items designed to assess the knowledge regarding varicella zoster virus.

Result: Unfortunately many of the dental students were not aware of this varicella zoster. Only $39 \%$ of the total population surveyed were aware of varicella zoster virus. The knowledge about this disease is poor among theDental students.

Conclusion: From the above survey it was observed that dental students were not much aware of this disease.So we have to create an awareness among the dental students.
\end{abstract}

Copyright $\bigcirc 2017$ Induja M.P and Dhanraj. This is an open access article distributed under the Creative Commons Attribution License, which permits unrestricted use, distribution, and reproduction in any medium, provided the original work is properly cited.

\section{INTRODUCTION}

Varicella zoster virus (VZV) is one of eight herpesviruses known to infect humans. VZV infections are species-specific to humans. It causes chickenpox (varicella), a disease most commonly affecting children, teens and young adults and herpes zoster (shingles) in older adults; shingles is rare in children. VZV is known by many names, including chickenpox virus, varicella virus, zoster virus, and human herpesvirus type 3 (HHV-3) VZV multiplies in the lungs, and causes a wide variety of symptoms (5). After the primary infection (chickenpox), the virus goes dormant in the nerves, including the cranial nerve ganglia, dorsal root ganglia, and autonomic ganglia. Many years after the patient has recovered from chickenpox, VZV can reactivate to cause neurologic conditions.Symptoms usually occurs for 7 to 10days. In some cases, Primary varicella leads to a serious cause. It may cause hepatitis, pancreatitis, pneumonitis, encephalitis. The death rate of varicella zoster has been dropped for many children due to the vaccination of varicellazoster.

*Corresponding author: Induja M.P

BDS Saveetha Dental College and Hospitals, Poonamalle High Road, Chennai
Bacterial infection, phosphopretic neuralgia are the secondary complications. Unlike transmission from cases of varicella, transmission from cases of $\mathrm{HZ}$ appears to occur most commonly through direct contact with lesions, although there have been reports that suggested that airborne transmission occurs.(6)

In the prevaccine era, varicella was essentially a universally experienced infection of childhood in countries with a temperate climate; in the United States, approximately $98 \%$ of the population was seropositive for VZV by the age of 20 years (3).

Varicella zoster virus (VZV) causes varicella (or chickenpox) and establishes latency in nerve ganglia after the primary infection. The reactivation of virus later in life can cause mono- or polyneuropathy. The cranial nerves most commonly involved are five (herpes zoster or shingles), six, seven eight, nine and ten. In the present study we describe the oral lesions associated with VZV infections in normal children. In a 3 year period we examined 62 children, age 2 to 13 years old with diagnosed varicella and a 4 year old boy with herpes zoster at the 3 rd branch of the trigeminal nerve(4).. According 
to the clinical picture of varicella, the disease was defined as: group A mild cases; group B moderate cases; group C severe. The manifestations of varicella were: mild varicella 19 children, moderate 26 children and severe 17 children. The results of the present study indicate that the prevalence of oral manifestations of varicella is related to the severity of the disease. In 17 severe cases, oral lesions were always present and the number was between 5 to 30 . From 26 moderate cases, oral lesions were observed in 23 and the number was between 2 to 10. From 19 mild cases, oral lesions were present only in 6 cases and their number was 1 or 2 . Often varicella's oral lesions resemble manifestations of other entities, and this may cause differential diagnostics problems.(1)

\section{METHODS AND MATERIALS}

A descriptive design using survey method was used to determine the varicella zoster virus. Subjects were Indians including men and women. Convenient sampling technique was used to select the participants. Data was collected using a questionnaire. A questionnaire was circulated among various dental students of different colleges in Chennai. The questionnaire consists of demographic profile and questionnaire related to knowledge regarding varicella zoster virus .Closed ended questionnaire was constructed with a total of 10 items designed to assess the knowledge regarding varicella zoster virus (2). In this survey, a total of 100 subjects participated. Descriptive statistics was used for data analysis. The results were analysed and presented in tables and figures. The study was approved by the Institutional Review Board. Informed consent was obtained from the participants before the data collection.

\section{RESULTS AND DISCUSSION}

A total of 100 questionnaire were distributed and the responses were collected. The characteristics of their responses are tabulated.Unfortunately many of the dental students were not aware of this varicella zoster.The knowledge about this disease is poor among the Dental students.

We conclude that the most parsimonious explanation for this finding is that exposure to infectious virus from many sources is common and thus not a rate-limiting step to epidemic spread.The IP technique used here is helpful to detect a single varicella zoster infected cells in $24 \mathrm{hrs}$ after infection and makes plaque visible as brown spots within 40hrs after infection of cell culture.

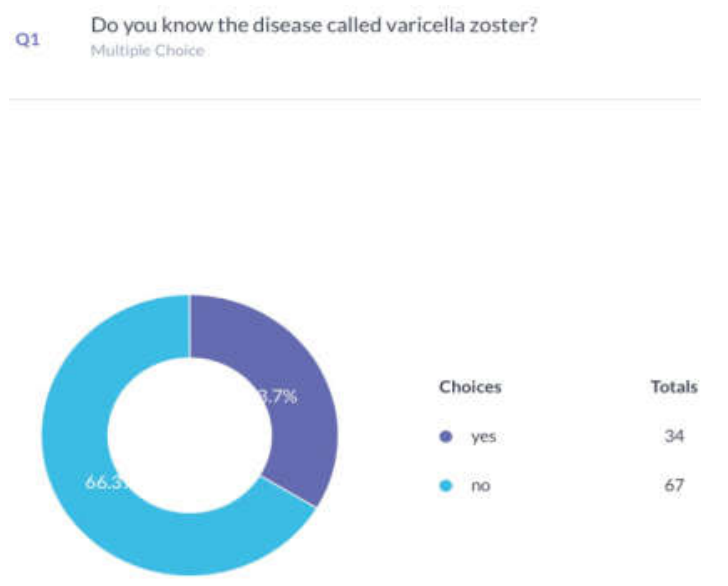

Q2 Does zoster vaccine cause shingles?

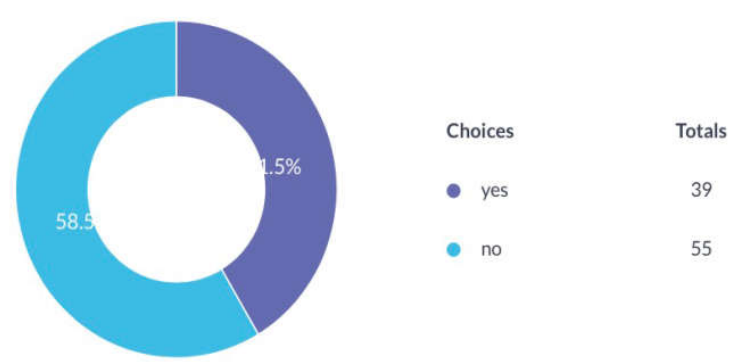

Q3 Can a person who has received the vaccine infect others with this viru

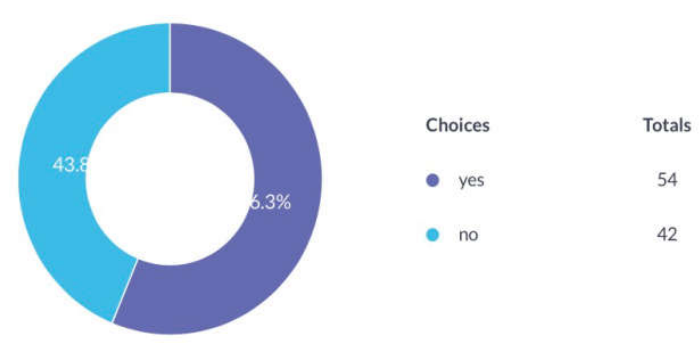

Q4 Who should not receive this zoster vaccine? Multiple Choice

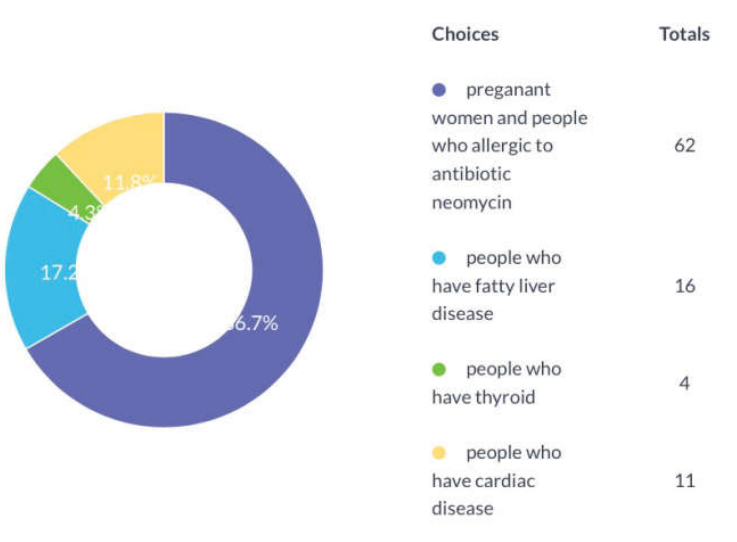

The diameter of infected cells is $0.5 \mathrm{~mm}$. Plaques 1 to $2 \mathrm{~mm}$ in diameter may be counted easily after an Incubation period of 72 hours, when cytotoxic effect is not usually detectable by microscopic observation, but $\mathrm{V}-\mathrm{Z}$ infected Cell foci are darkly stained by the IP technique(7). The staining specificity of $\mathrm{V}-\mathrm{Z}$ 
infected cells has been demonstrated by the disappearance of both nuclear and cytoplasmic staining absorption of specific $\mathrm{V}-\mathrm{Z}$ immune serum with $\mathrm{V}-\mathrm{Z}$ infected cells AND by the lack of cross reactions with human CMV and HSV when V-Z positive serum and conjugate were used at appropriate dilutions(9). The correlation between V-Zneutralising antibody needs to be established.The main advantage of IP plaque assay over classical $\mathrm{V}-\mathrm{Z}$ virus plaque assays is that of obtaining results earlier.Moreover, no solidifying is required.However,disadvantage of technique lies in the use of human serum, which must be selected to contain antibodies only to $\mathrm{V}-\mathrm{Z}$ virus and not to any other human herpesvirus.Several data suggest that V-Z virus and HSV share cells common antigens (8). This finding corroborates a

\section{Article History:}

Received $11^{\text {th }}$ January, 2017

Received in revised form $19^{\text {th }}$ February, 2017

Accepted 22 ${ }^{\text {nd }}$ March, 2017

Published online $28^{\text {th }}$ April, 2017 s among viruses cation during a (10). Rather, as is probably the $s$ together with gatherings (7). whole-genome sequencing of VZV has enabled us, for the first time, to study the dynamics of VZV transmission and evolution during a localized outbreak in Guinea-Bissau in 2001.Multiple neurologic complications after VZV reactivation include $\mathrm{PHN}$; vasculopathy; myelitis; necrotizing retinitis; and zoster sine herpete (pain without rash). Many may occur without rash and are difficult to recognize. Virologic confirmation requires testing the CSF for VZV DNA and anti-VZV IgG. Immediate treatment with antiviral agents may be warranted.

\section{CONCLUSION}

From the above survey it is Proved that dental students are not that much aware of this disease. So we have to create an awareness among the dental students. The varicella vaccination program in the United States has resulted in dramatic declines in rates of varicella disease in all age groups including infants and adults(10). The determination of neutralizing antibody titre by the IP plaqueassay represents a valid improvement over methods presently used for measuring neutralizing antibodies to $\mathrm{V}-\mathrm{Z}$ virus, as far as rapidity of results is concerned.

\section{References}

1. D.Scott Schmid and Aisha O.Jumaan. American Society for Microbiology. Clin Microbiol Rev. 2010 Jan; 23(1): 202-217. doi: 10.1128/CMR.00031-09.

2. Ampofo, K., L. Saiman, P. LaRussa, S. Steinberg, P. Annunziato, and A. Gershon. 2002. Persistence of immunity to live attenuated varicella vaccine in healthy adults. Clin. Infect. Dis. 34:774-779. [PubMed]

3. Nichols RA, Averbeck KT, Poulsen AG, al Bassam MM, Cabral F, Aaby P, Breuer J. 2011. Household size is critical to varicella-zoster virus transmission in the tropics despite lower viral infectivity. Epidemics 3:18.10.1016/j.epidem.2010.11.003 [PMC free article] [PubMed] [Cross Ref]

4. Arvin, A. M. 1996. Immune responses to varicellazoster virus. W. B. Saunders, Philadelphia, PA. [PubMed]

5. Gnann JW, Jr., Whitley RJ. Clinical practice. Herpes zoster. N Engl J Med. 2002; 347:340-346. [PubMed]

6. Gilden DH, Kleinschmidt-DeMasters BK, LaGuardia JJ, Mahalingam R, Cohrs RJ. Neurologic complications of the reactivation of varicella-zoster virus. $N$ Engl $J$ Med. 2000; 342:635-645. [PubMed]

7. Wutzler P, Farber I, Wagenpfeil S, et al. Seroprevalence of varicella-zoster virus in the German population. Vaccine. 2001; 20:121-4. [PubMed]

8. Lee BW. Review of varicella zoster seroepidemiology in India and Southeast Asia. Trop Med Int Health. 1998; 3:886-90. [PubMed]

9. Guess HA, Broughton DD, Melton LJ. Populationbased studies of varicella complications. Pediatrics. 1986; 78(Suppl 4):723-7. [PubMed]

10. Quinlivan M, Sengupta N, Papaevangelou V, Sauerbrei A, Grillner L, Rousseva R, Hague R, Lutsar I, Jogi P, Lea A, Grytchol R, Alain S, Breuer J. 2013. Use of oral fluid to examine the molecular epidemiology of varicella-zoster virus in the United Kingdom and continental Europe. J. Infect. Dis. 207:588593.10.1093/infdis/jis649 [PMCfreearticle][PubMed] [Cross Ref]

\section{How to cite this article:}

Induja M.P and Dhanraj (2017) ' Knowledge And Awareness Of Varicella Zoster Among The Dental Students', International Journal of Current Advanced Research, 06(04), pp. 3172-3174.

DOI: http://dx.doi.org/10.24327/ijcar.2017.3174.0215 